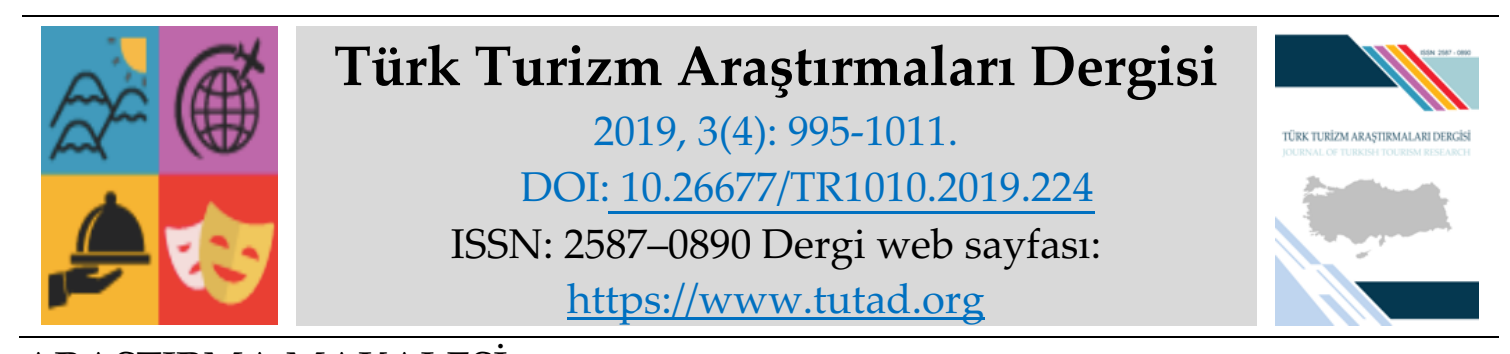

ARAȘTIRMA MAKALESI

\title{
Otel İşletmelerinin Mutfak Departmanında Örgütsel İklim ve Liderlik Stilleri İlişkisinin İncelenmesi: Bir Zincir Otel İşletmesi Örneği
}

Öğr. Gör. Ozan GÜNGÖR, Aydın Adnan Menderes Üniversitesi, Davutlar Meslek Yüksekokulu, Aydın, e-posta: ozangungor@adu.edu.tr

ORCID: https://orcid.org/0000-0002-7287-5899

Dr. Öğr. Üyesi Hakan ATAY, Aydın Adnan Menderes Üniversitesi, Turizm Fakültesi, Aydın, eposta: hatay@adu.edu.tr ORCID: https://orcid.org/0000-0003-4080-8250

Öz

Zincir otellerde çalışma ortamındaki örgütsel iklim ile mutfak departmanı yöneticisinin sergilediği ve departman çalışanlarının algıladığı liderlik stili arasında anlamlı bir ilişki olduğu düşünülmektedir. Bu düşünceye bağlı olarak araştırmanın amacl; zincir otel işletmelerinde mutfak departmanlarındaki örgütsel iklim ve mutfak şeflerinin liderlik stilleri arasında bir ilişki olup olmadığını araştırmak olarak belirlenmiştir. Bu amaç doğrultusunda zincir otel işletmelerinde örgütsel iklim ile liderlik, stillerinin ne derecede ilişkili olduğu belirlenmeye çalışılmıştır. Araştırma bir tarama modeli olup ampirik yaklaşım tercih edilmiştir. Nicel araştırma yaklaşımından yararlanılmıştır. Veri toplama tekniği olarak anket tekniği kullanılmıştır. Veri toplama aracı olarak kullanılan anket formu demografik sorular (10 soru), örgütsel iklim (25 ifade) ve liderlik stilleri (34 ifade) ölçekleri ile toplamda üç bölümden oluşmaktır. Araştırmanın evrenini oluşturan 16 tesisli zincir otel işletmesinin 12 tesisinde yer alan çalışanlar örneklem olarak alınmıştır. Bu araştırmanın temel amacı olan, örgütsel iklim ile liderlik stilleri arasında anlamlı bir ilişkinin olup olmadığını belirlenmeye yönelik olarak yapılan Pearson Korelasyon Analizi sonucuna göre, örgütsel iklim ile liderlik stilleri arasında pozitif ve orta düzeyli bir ilişki olduğu ortaya çıkmıştır.

Anahtar Kelimeler: Örgüt İklimi, Liderlik Stilleri, Zincir Oteller.

Makale Gönderme Tarihi: 12.06.2019

Makale Kabul Tarihi: 03.10.2019

\section{Önerilen Atıf:}

Güngör, O. ve Atay, H. (2019). Otel İşletmelerinin Mutfak Departmanında Örgütsel İklim ve Liderlik Stilleri İlişkisinin İncelenmesi: Bir Zincir Otel İşletmesi Örneği, Türk Turizm Araştırmaları Dergisi, 3(4): 995-1011.

(C) 2019 Türk Turizm Araştırmaları Dergisi. 


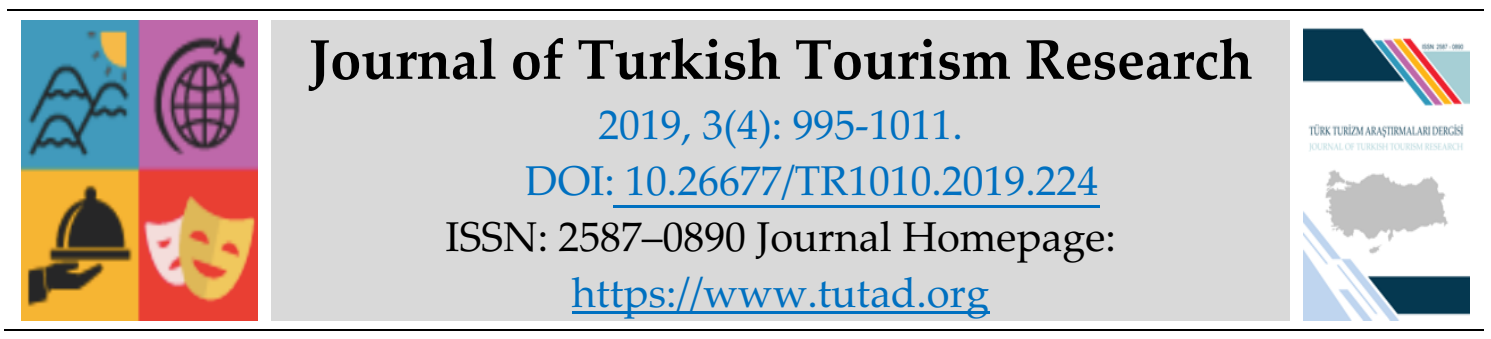

RESEARCH PAPER

\title{
Investigating the Relation Between Organization Climate and Leadership Styles in Kitchen Department at Hotels: Sample of Chain Hotel Group
}

Lecturer Ozan GÜNGÖR, Aydın Adnan Menderes University, Davutlar Vocational School, Aydın, e-mail: ozangungor@adu.edu.tr ORCID: https://orcid.org/0000-0002-7287-5899

Assistant Prof. Dr. Hakan ATAY, Aydın Adnan Menderes University, Faculty of Tourism, Aydın, e-mail: hatay@adu.edu.tr

ORCID: https://orcid.org/0000-0003-4080-8250

\begin{abstract}
It has been thought that there is a significant relation between organizational climate and leadership style which is performed by the executive chef and is perceived by the kitchen staff at work place in hotel chains. Depending on this thought, the aim of this research is whether there is a significant relation between organizational climate at kitchen departments and leadership styles of executive chefs at chain hotels. Empirical approach has been preferred and the research has screening model. Quantitative research methods have been used. Survey method has been preferred as data collecting method. Survey form has 3 parts which are demographical questions (10 questions), organizational climate scale (25 statements) and leadership styles scale (34 statements). The universe is kitchen staff at 16 hotels of chain hotel group. The sample is kitchen staff at 12 hotels of chain hotel group which accepted to participate to the research. According to result of Pearson Correlation Analysis to determine whether there is a significant relation between organizational climate and leadership styles which is the main aim of this research, it has been determined that there is positive and middle level relation between organizational climate and leadership styles.
\end{abstract}

Keywords: Organizational Climate, Leadership Styles, Chain Hotels.

Received: 12.06 .2019

Accepted: 03.10.2019

\section{Suggested Citation:}

Güngör, O. and Atay, H. (2019). Investigating the Relation Between Organization Climate and Leadership Styles in Kitchen Department at Hotels: Sample of Chain Hotel Group, Journal of Turkish Tourism Research, 3(4): 995-1011.

(C) 2019 Türk Turizm Araştırmaları Dergisi. 


\section{Gíriş}

İnsanların gelir seviyelerinin artması, teknolojik gelişmelerin sağladığı kolaylık ile tatil temel ihtiyaçlardan biri haline gelmektedir. Tatil ihtiyacının artmasıyla konaklama tesisleri de rakipleri karşısında başarılı olmak ve varlığını etkin bir şekilde sürdürebilmek için işletmenin güçlü bir örgütsel iklime sahip olması gerekmektedir.

Örgütsel iklim, çalışanların işyerinin psikolojik ortamına ilişkin algısıdır. Çalışanların başarı güdülerinde, verimlilik ve etkinliklerinde örgütsel iklimin olumlu algılanması önemli bir yere sahiptir. Bu nedenle örgütsel iklim algılaması ile çalışan performansı arasında bir ilişkinin olduğu varsayılabilir. Çalışanların performansı, başka birçok yönetsel ve örgütsel faktörün yanında, örgütsel iklimin olumlu algılanmasına bağlıdır (Tutar ve Altınöz, 2010). Otel işletmeleri örgütsel iklimi güçlendirmek için personel geceleri, personel doğum günü kutlamaları, ayın elemanı seçme ve çeşitli aktiviteler ile çeşitli organizasyonlar düzenlenmektedirler. Bu iklimi yönetebilmek için de örgütsel iklimi benimseyen liderlere ihtiyaçları vardır.

Liderlik, belirli şartlar altında, belirli kişisel veya grup hedeflerine ulaşmak üzere, bir kimsenin başkalarının faaliyetlerini etkilemesi ve yönlendirmesi olarak tanımlanabilir (Koçel, 2007). 1980'li yıllarda yeni dünya düzeninde liberalliğin ve küreselleşmenin getirmiş olduğu yeni ihtiyaçlarla birlikte, yeni liderlik akım ve kavramlarının türediği görülmektedir (Saylı ve Baytok, 2014). Lider kelimesi daha yaygın olarak kullanılsa da koç, mentor gibi yeni kavramlar da yavaş yavaş organizasyonlarda yerini almaktadır (Koçel, 2007).

Otel işletmelerinde iyi bir örgütsel iklim oluşturmak için iyi bir lidere ihtiyaç duyulmaktadır. Otel işletmelerinde iyi bir örgütsel iklimin yaratılması, personelin belirlenen hedeflere ulaşabilmesi için arzu ve ihtiyaçlarının saptanması gerekmektedir. Daha sonra bu işgörenler onları güçlendirecek, çalışma isteklerini ve enerjilerini arttıracak bir liderin etrafında toplanmalıdır (Hocaniyazov, 2008).

Günümüzde iyi yemek yapan bir mutfak yöneticisinin iyi bir aşçbaşı olduğunu düşünmek yanıltıcı olabilir. Bu alanda iyi bir yönetici olabilmek için yönetim ve pazarlama bilgisine sahip olmak gerekmektedir. Menü planlama, maliyet kontrol gibi hesaplamalar için muhasebe bilgisine, mutfak organizasyonu, sevk idaresi için yönetim bilgisini; müşterinin istek ve ihtiyaçlarını algılayıp karşılayabilmek için pazarlama becerisini barındırması gerekmektedir (Rızaoğlu ve Hançer, 2005). Mutfak bölümü sürekli üretim halinde olan bir alan olduğu için çalışanların yönetilmesi ve ortamdaki iş entegrasyonu işletmenin örgütsel iklimi ile gerçekleşmektedir. Mutfak ekibinin performansı, çalışma ortamındaki motivasyonu örgütsel iklim ile doğru orantılıdır.

Mutfakta usta-çırak ilişkisi olması diğer bölümlere göre farklı bir çalışma atmosferi yaratmaktadır. Kalitesiz hammadde, yetersiz donanım, uygun çalışma koşullarının olmaması, maaşların geç ödenmesi, sezonluk çalıştırılma gibi zorlukların hem mutfak yöneticisinin liderlik stillerini hem de çalışanların örgütsel iklimini etkilediği ve bunlarla ilişkisi olabileceği düşünülmektedir. Bu düşünceden yola çıkılarak örgütsel iklim ve liderlik stilleri arasındaki ilişkinin saptanması amaçlanmıştır.

\section{KAVRAMSAL ÇERÇEVE}

$\mathrm{Bu}$ araştırmada örgüt iklimi ve liderlik stili arasında bir ilişki olup olmadığ1 incelenmektedir. Bu bağlamda öncelikle örgütsel iklim kavramı ve liderlik stilleri ile ilgili literatür taramasına yer verilmektedir. 


\section{Örgüt İklimi Kavramı}

Etimolojik olarak Yunancada eğilim (temayül) anlamını taşıyan iklimin, kelime anlamı atmosfer ve havadır. Isı ve basınç gibi fiziksel olayları tanımlarken de kullanılan iklim, örgüt üyelerinden birinin iç çevreyi nasıl betimlediği anlamını taşıyan başka anlamlarda da kullanılmaktadır (Karcıoğlu, 2001).

“Örgüt” ve "İklim” kelimeleri ayrı ayrı incelendiğinde; Leavitts örgütün, "görev, yapı, bireyler ve teknolojik boyutlardan meydana geldiğini" ifade ederken (Hellriegel ve Slocum, 1974), Mac Gregor ise iklimi, "yönetimsel bir faaliyet, yönetici ve astları arasındaki ilişkiler" olarak tanımlamıştır (Gül, 2012). Örgüt iklimi kavramı ilk olarak Lewin, Lippitt ve White'ın 1939'daki çalışmasında görülmektedir. Araştırma, genç erkeklerden oluşan bir grup üzerinde deneysel olarak yaratılan sosyal iklim üzerine odaklanmıştır. Fakat araştırmacılar, örgütsel iklimi ölçme ve boyutlandırmada başarısız olmuşlar ancak sosyal iklim ile liderlik stilleri arasındaki ilişkiyi vurgulamıştır (Kundu, 2007).

Campbell, Dunnette, Lawer ve Weick (1970), örgüt iklimini, örgüt üyelerinin çevreleri ile ilgilenme biçimleri ile şekillenen ve belirli bir örgüte özgü olan tutum/davranışlar seti olarak açıklamışlardır. Bu davranışlar o örgüte özgü olduğu için, örgütün zamanla diğer örgütlerden ayrışmasını sağlamakta ve bir örgüt kimliği haline dönüşebilmektedir (Forehand ve Gilmer, 1964). Dolayısıyla örgütsel iklim kuramının hem kişisel (psikolojik iklim) hem örgütsel hem de çoklu boyutları olduğu öne sürülmektedir (James ve Jones, 1974). Ayrıca Cherrington da (1989), örgüt iklimini, örgüt kişiliği olarak ele alınabilecek davranış özellikleri olarak görmektedir ve bunların örgütü diğer örgütlerden ayıran bir yönü vardır. En iyi bilinen örgütsel iklim boyutları James ve Jones (1974) ile James ve James (1989) tarafından geliştirilmiş olup iş basitleştirme, hedef vurgusu, büyüme ve ilerleme fırsatları ve profesyonel takım ruhunu içermektedir (Bellou ve Andronikidis, 2009).

Örgüt ikliminin oluşum sürecinde çevresel, kişisel ve sonuç değişenler olmak üzere üç çeşit değişken grubu etki etmektedir. Çevresel değişkenler örgütün hacmi, yapısı ve ekonomik koşulları gibi dış etkenlerden oluşmaktadır. Kişisel değişkenler ise örgüt üyelerinin bireysel yetenekleri, işe ilgileri, kişilikleri, becerileri gibi niteliklerdir. Çevresel ve kişisel değişkenlerin bir araya gelmesi ile de sonuç değişkenleri ortaya çıkmaktadır (Halis ve Uğurlu, 2008). Sözgelimi bireysel amaçlar ve örgüt amaçlarının birleştirilmesi, birey ve örgüt arasındaki psikolojik anlaşma, örgüte aidiyet hissinin oluşması gibi örgüt iklimine özgü nitelikler ortaya çıkmaktadır (Tinaz, 2013).

\section{Örgüt İkliminin Boyutları}

Örgüt ikliminin boyutları ile örgütsel iklimi etkilediği varsayılan etmenler ifade edilmektedir (Ertekin, 1978). 1968' de Litwin ve Stringer, örgüt iklimini; yapı, sorumluluk, ödül, risk, sıcaklık, destek, standartlar, çatışma ve kimlik olarak dokuz boyutta incelemişlerdir (Kuei vd, 1997; Bal ve Berkin, 2010; Holloway, 2012).

Waters, Roach ve Batlis 1974'te, örgütsel iklim boyutları üzerine yaptıkları araştırmaların faktör analizi sonucunda dört ile yedi bağımsız faktör elde etmişlerdir. Sims ve LaFollette 1975 yılında yaptıkları araştırmada, Litwin ve Stringer tarafından geliştirilen dokuz boyutlu ölçeğin sekiz boyutunun insan odaklı, sadece yapı boyutunun diğerlerinden farklı olduğunu araştırmalarında ifade etmişlerdir (Kuei vd., 1997). Hangi yaklaşımın kabul göreceği genel olarak araştırmaya bağlı olarak değişkenlik gösterebilir (Patterson, vd., 2005). 


\section{Örgüt İkliminin Sınıflandırılması}

Literatür taramasında örgüt ikliminin iki farklı kategoride sınıflandırıldığı görülmüştür. Bunlar yönetim ve davranış tarzları ile liderlik özellikleridir.

\section{Yönetim ve Davranış Tarzlarına Göre Örgütsel İklim}

Araştırmacılar örgütsel iklim tiplerini daha iyi analiz edebilmek için liderlerin yönetim ve davranış tarzlarına göre sınıflara ayırmışlardır. Bu sınıflama aşağıdaki gibidir:

Açık iklim: Bu iklimin özellikleri astlara güven, iletişimde şeffaflık, destekleyici liderlik, çalışanların özerkliği olarak sıralanabilir. Açı iklimde yöneticiler ve işgörenler senkronize olduğundan işgörenler görevlerini büyük istekle yaparlar. Eleştirilere açk ve anlayışlı olan yöneticiler çalışanların yönetsel kararlara katılmalarını desteklerler (Hocaniyazov, 2008).

Otonom iklim: Çalışanların kendi kendilerini yönettiği ve karar vermede yöneticilerinin onlara imkân verdiği bu iklimde, sorunları birlikte çözme ve örgütün hedeflerine ulaşma konusunda çalışanlar yeterli motivasyona sahiptirler (Tutar ve Altınöz, 2010).

Kontrollü iklim: Bu iklimde, işgören görev ve sorumluluklarını yerine getirirken esnekliğe kontrollü bir şekilde izin verilir. Bu esneklik işgörende yüksek bir motivasyonun oluşmasını sağlar (Tutar ve Altınöz, 2010).

Samimi iklim: Sosyal gereksinimlerin giderilmesinin ön planda olduğu bu iklim türünde çalışanlar ile yöneticiler birbirleriyle arkadaş̧̧a ilişkiler kurarak mutlu bir aile imajı verirler (Halis ve Uğurlu, 2008).

Babacan iklim: Çalışanlarla birlik olmak ve onları kontrol etmek isteyen başarısız yönetici ile moralleri düşük işgörenlerin oluşturduğu bir iklim türüdür. Yöneticiler işgörenlerin sosyal ihtiyaçlarını yeterince karşılayamadıkları için çalışanların çalışma arzusu ve işe dönüklük düzeyleri düşüktür. Yöneticiler işgörenlerle birlikte çalışmaktan pek keyif almazlar (Özdoğan, 2014).

Kapalı iklim: Verimlilik vurgusu yüksek fakat uygulamada verimliliğin düşük olduğu bu iklim türünde yönetici çalışanların başarılı olması için kolaylık sağlamaz. Yöneticiler emredici olduğundan iş görenlerin motivasyonu, iş tatmini ve çalışanlar arasındaki samimiyet oldukça düşüktür. Sonucunda örgüt içinde tartışma ve çatışma görülür (Çakır, 2010).

\section{Liderlik Özelliklerine Göre Örgütsel İklim}

Litwin ve Stringer'in 1968' deki yaptıkları araştırmalar sonucunda liderlik özelliklerinin örgütsel iklime göre farklılık gösterdiğini ifade etmişlerdir (Halis ve Uğurlu, 2008; Pala, 2011):

Otokratik Yapılı İklim: İş çevreleri kesin çizgilerle çizilmiş, rolleri tanımlanmış olan örgüt üyeleri bu çerçeve içerisinde görevleri ile ilgili olarak tam performans göstermekle sorumludurlar. İletişim dikey biçimde resmi olarak yapılır. Pozisyonun gerektirdiği ciddiyet ve emir-komuta hiyerarşisi yönetimin bütün kademelerinde uygulanır ve bu kurallara uymayanlar cezalandırılır.

Demokratik Yapılı İklim: Bu tip iklimde örgüt üyeleri arasında dayanışma duygusu ön plandadır. Takım ruhu, grup toplantıları, gruba bağlılık öne çıkar. Bütün aşamalarda kararlara katılım açıktır. Ceza yerine kişisel gelişim ve cesaretlendirme desteklenir. Bireylere saygı işten önce gelir. İş tatmini yüksektir ancak etkinlik orta derecededir. 
Başarıya Yönelik İklim: Bu iklim tipinde yüksek verimlilik vurgulanmaktadır. Yönetim, hedeflere giden yolda yaratıcı geri dönüşleri ve düşünceleri destekler. Çalışanlar kendi hedefleri belirlemeye yönelik teşvik edilir. Ödül sistemi interaktif şekilde kullanılır. Bu iklim tipinde çalışanların hep daha iyisini gerçekleştirme eğiliminde olacakları düşüncesinden birbirlerinin yardımına koşması ve daha hızlı etkileşim sağlamak için resmi olmayan iletişim dili kullanmaları istenir.

\section{Liderlik Kavramı}

Grup içerisindeki bireyin sergilemiş̧ olduğu bir davranış olan liderliğin tarihi insanlığın tarihi kadar eskidir. Sosyal varlıklar olarak bir arada yaşama eğiliminde olan insanlar, gruplardan başlayarak toplumlara kadar farklı düzeylerde etkileşimin olduğu birlikler oluşturmuşlardır. Bu birliklerde bazı bireyler diğer bireylerden daha baskın ve ön planda (sevk edici, idare edici, düzen kurucu) yer almışlardır (Özel, 1998; İbicioğlu, Özmen ve Taş, 2009).

Liderlik, İngilizce "lead" fiilinden türetilmiş "leadership" kelimesinden gelmektedir. Türkçe'de; önderlik etmek, yol göstermek, rehberlik etmek anlamlarını taşır (Eraslan, 2004). Türkçe çevirisi önderlik, yönderlik, yederlik olarak literatüre geçmiş olsa da "liderlik" kelimesi daha çok kabul görmektedir (Şiş̧man, 2004).

Liderlik üzerine çok sayıda çalışma yapılmış ve bu çalışmalarda yüzlerce liderlik tanımı oluşturulmuştur. Bu tanımların içeriği kabaca analiz edilecek olursa liderliğin genel bir tanımı şu şekilde yapılabilir (Güney, 2012; Yılmaz, 2008; Can, Akgün ve Kavuncubaşı, 2001; Zel, 2001; Gülertekin, 2013; Erçetin, 1998): Liderlik, ön plana çıkarak amaçları belirlemek ve insanları her yönden etkileyerek grubun gücünü yüklenebilmek ve böylelikle grup dinamiğine bir anlam kazandırmak; farklı istekleri görüp bunları karşılayarak az çatışma ve güçlü işbirliği duygusu oluşturup insanları kendiliğinden ikna ederek güçlü bir moral duygusuyla en kısa yoldan başarıya ulaştırmak; analitik düşünceyle bilinen kalıpların ötesinde kararlar alıp sosyal hareketleri kontrol ederek hayranlık uyandırmak şeklinde tanımlanabilir.

\section{Liderlik Stilleri}

Liderlik stilleri geleneksel ve modern olmak üzere başlıca iki kategoride sınıflandırılmaktadır. Geleneksel stiller otokrotik, demokratik ve başıboş/tam serbestlik tanıyan liderlik stilleri olarak üç başlıkta; modern stiller ise dönüşümcü, etkileşimci, karizmatik stiller olmak üzere incelenebilir.

\section{Geleneksel Liderlik Stilleri}

Liderlik dizesi kuramı (Continuum of Leadership), Robert Tannenbaum ve Varrem H. Schimidt'in Harward Üniversitesi'nde 1950'li yıllarda yaptıkları araştırmalara dayanır. Bu kurama göre bir liderin liderlik biçimi, otokratik-demokratik-başıboş liderlik biçimi çizgisinde bir yerdedir. Liderin bu yerdeki biçemi, başkalarından farklı olabilir; ama liderlik biçimi, bu üç liderlik biçiminden biridir (Başaran, 1998).

Otokrotik Liderlik: Baskıcı yönetimi tercih eden, astların emirlerine kayıtsız şartsız itaat etmeleri isteyen ve yetkilerini bu yönde kullanan lider tipidir. (Akat, 1984). Gruba danışmadan emir veren, gruba yapacağı işler hakkında bilgi vermeyen, bütün kararları tek başına alan davranış özelliği gösterir (Özkalp, 1988). Genellikle bu tarz yöneticiler kendi çıarları için hareket eder ve astlarını sürekli ezerler (Akat, 1984). 
Demokratik Liderlik: Yönetimde insan ilişkilerine değer verilen neo-klasik dönemde popülerliği artmıştır (Bakan vd., 2013). Yönetim yetkisini grup üyeleri ile paylaşan (Eren, 2003), gruba danışmadan hareket etmeyen, grup üyelerinin fikirlerine saygı gösteren (Özkalp, 1988), kararların, grup üyelerinin görüşlerinden etkilenmesine ve biçimlenmesine olanak sağlayan lider tipidir (Başaran, 1998).

Başıboş-Tam Serbestlik Tanıyan Liderlik: Tam serbestlik tanıyan liderler, yetkiye sahip çıkmamakta ve yetki kullanma haklarını tamamıla izleyenlerine bırakmaktadırlar (Eren, 2003). Bu stil esnek, açık iletişimci, motive edici ve yeniliği özendirici olmakla beraber eksik eşgüdüm, hedef belirsizliği, kontrol eksikliği ve düşük dayanışma gibi olumsuz çıtılara da neden olabilir (Taşkıran, 2005).

\section{Modern Liderlik Stilleri}

Yönetim paradigmalarındaki değişimler sonucunda eski teoriler zamanla etkisini kaybetmekte ve yeni teoriler ortaya çıkmaktadır. Bu süreçte, klasik teoriler tamamen reddedilmemekte aksine, onların oluşturduğu bilgi birikimi, yeni teoriler ve modellerin geliştirilmesine etki yapmaktadır (Saylı ve Baytok, 2014). James MacGregor Burns, 1974 yılında ilk Dönüşümsel ve Etkileşimci liderlik modelleri arasındaki karşılaştırmayı karizmatik liderlik üzerindeki etkileyici çalışmasıyla yapmıştır. Bernard Bass ve onun yardımcısı Bruce Avolio 1985 yılında Çok Yönlü Liderlik (Multifactor Leadership Questionnaire) anketi kullanarak bağımsız ve birbirini tamamlayan iki yaklaşım bulmuştur (Korkmaz, 2007).

Dönüşümcü (Dönüştürücü) Liderlik: Burns'e göre, “dönüşümcü liderlik; bir ya da birkaç kişinin, izleyenleri veya birbirlerini daha yüksek motivasyona ve ahlaka teşvik etmelerine dayalı bir ilişkiye girdiklerinde gerçekleşmektedir" (Yavuz, 2009; Akbolat, Işık ve Yılmaz, 2013; Kılıç, vd., 2014). Dönüşümcü liderler, izleyenlerinin yeteneklerini keşfederek ve geliştirerek onların motivasyonlarını yükselterek daha fazla verim almayı hedefler (Sabuncuoğlu ve Tüz 2003). Grup üyelerinin vizyon ve misyon sahibi olmalarını sağlarlar. Çalışanların potansiyellerinin farkında olmalarını sağlayarak, işi daha iyi yapacaklarına inandırırlar (Eren, 2003).

Etkileşimci Liderlik: Grup üyelerinin beklentilerini anlayan, onların beklenen performansı sergilediklerinde karşılında alacakları ödülü açıkça anlatan bir lider tipi olarak tanımlanmıştır (Yavuz ve Tokmak, 2009). Etkileşimci liderlik, liderin grup içinde sahip olduğu hiyerarşik yetkiye ve yasal otoriteye dayanmaktadır. Bu liderler, iş standartlarına, belirlenen görevlere ve işe yönelik amaçlara önem vermektedir (Taşkıran, 2005). Etkileşimci liderlik, liderler ile izleyenleri arasında karşılıklı etkileşime dayalıdır. Bu süreçte izleyenlerin kendilerinden beklenilen performansı göstermesi durumunda ihtiyaçları karşılanır (Wofford, 1998). Bu tarz lider verilen görevin tamamlanmasına odaklanmıştır. Etkileşimci liderler çalışanların performanslarını etkilemek için örgüt içindeki ödül ve ceza sistemlerine tam olarak güvenmektedirler (Taşkıran, 2005).

Karizmatik Liderlik: Karizmatik lider, sahip olduğu karizma yaratan özellikleri ile başkalarını kendi istediği yönde davranmaya ve üstün performansa sevk edebilen kişidir (Koçel, 2007). Karizmatik liderler iyi ittifak oluştururlar, izleyenleri ile empati yaparlar, ne kadar meşgul olursa olsunlar birisi kendileriyle konuşmak istediğinde zaman yaratarak onları dinler, değerli hissetmelerini sağlayarak dinlenmenin verdiği rahatlığ ve huzuru insanlara hissettirirler (Kets de Vries, 2007). 


\section{Örgüt İklimi ve Liderlik Stilleri Arasındaki İlişki}

Örgüt iklimi ile ilgili ampirik çalışmalar 1968'de Lewin ve Stringer'in "motivasyon ve örgütsel iklim" konusunda birlikte çalışmalarıyla başlamış ve Tiguiri ve Litwin'in "örgütsel iklim kavramı" başlıklı araştırmalarıyla devam etmiştir. Litwin ve Stringer, grup üyelerine yönelik örnek bir liderlik davranışın iklimi değişebileceğini öne sürmüşlerdir (Hocaniyazov, 2008). Liderin ilk ve en önemli sorumluluğu denetlemek, yöneltmek ve örgütün farklı bölümleri arasındaki ilişkileri eşgüdümlemektir. Bunları sağlamak isteyen bir lider çeşitli davranışlar sergiler, karmaşık bir ilişkiler düzeni içinde görülebilir. Liderin bu davranışları örgütsel iklimin oluşmasında önemli oranda etkili olur (Ertekin, 1978). Örgütsel iklim kuramcıları farklı liderlik stilleri uygulamalarının örgütlerde farklı boyutlarda örgütsel iklim algılamalarına yol açtığını ifade etmişlerdir (Ergeneli, 1995). Örneğin:

Otoriter yapılı iklimin; örgüt ortamında baskın bir erk güdüsüne, işe tatminsizlik ve örgüte karşı olumsuz davranışlara ve düşük verimliliğe neden olabileceği;

Arkadaşça ilişkilere dayanan iklimin; örgüte karşı olumlu davranışlar, yüksek düzeyde bir arkadaşlık güdüsü ve yüksek doyumluluk sağlayabileceği;

Başarıya dönük iklimde; örgüte karşı olumlu tutum ve davranışlar, işe karşı aşırı tatmin olma ve yaratıcılıktaki yüksek düzey sağlayabileceği öngörülmektedir.

$\mathrm{Bu}$ bağlamdan hareketle araştırmanın amacı bir zincir otel işletmesinin mutfak departmanında örgütsel iklim ve liderlik arasında bir ilişki olup olmadığını araştırmaktır.

Bu çerçevede bu araştırmanın hipotezi:

Ho: Mutfak bölümündeki örgütsel iklim ile mutfak şefinin liderlik stili arasında anlamlı bir ilişki yoktur.

H1: Mutfak bölümündeki örgütsel iklim ile mutfak şefinin liderlik stili arasında anlamlı bir ilişki vardır.

şeklinde kurulmuştur.

\section{YÖNTEM}

Araştırma tarama modelinde olup nicel ampirik yaklaşım tercih edilmiştir. Bu yaklaşımda araştırma alanı ile ilgili önceden ortaya koyulan bilgilerle sağlanan ya da olasılığı varsayılan hipotezlerin test edilmesi söz konusudur.

\section{Evren ve Örneklem}

Araştırmanın evreni bir zincir otel işletmesine dâhil 16 adet konaklama işletmesinin mutfak çalışanlarıdır. Örneklem olarak bu konaklama işletmelerin mutfak bölümde çalışanlar gönüllük esasına göre seçilmiştir.

Araştırma evrenini belirlemek, verilerin hangi birimlerden elde edileceğini ve araştırma sonucunda yapılacak genellemelerin kimleri veya neleri kapsayacağını saptamak anlamını taşımaktadır. Bilimsel araştırmada çalışma evreninin tamamına ulaşılabileceği gibi çalışma evreni içerisinden belirli bir yöntem ile seçilebilecek örneklem aracilığıyla da ana kütle temsil edilebilir (Ural ve Kılıç, 2006). Araştırmada olasılıklı olmayan örnekleme yönteminden kolayda örnekleme kullanılmıştır. Olasılıklı olmayan örnekleme, ana kütleyi temsil etmek amacıyla seçilecek örneğe girecek birimlerim tesadüfi olarak seçilmeyip araştırıcının kendi inisiyatifi ile seçtiği birimlerden oluşan örnekleme olarak tanımlanır. Kolayda örnekleme yönteminin esası, ana kütleye ait ulaşılan her birimin örnekleme dâhil edilmesidir (Yazıcıoğlu ve Erdoğan, 2007). 
Yani $\mathrm{n}$ tane nesne arasından $\mathrm{n}$ tanelik bir örneklem seçilmesi, $\mathrm{n}$ nesneli her örneklemin seçilme şansının eşit olmasıdır (Newbold, 2000).

Araştırma evreni zincir bir otel işletmesi olduğu için temsil gücü yüksek bir katılımcı grubunu araştırmaya dâhil etme amacı güdülmüştür. Zincir işletmelerinin 16 adet oteli mevcuttur. 1 otel mesafe uzaklığından ve 3 otel iş yoğunluğundan araştırmanın uygulamasına katılamamıştır. Dağıtılan toplam 480 anketten 389 adet anket analize uygun bulunmuştur.

\section{Verilerin Toplanması}

Veri toplama tekniği olarak anket tekniği kullanılmıştır. Araştırmanın amacına yönelik veri tekniğinin ekonomik olması, geniş kitlere kısa sürede ulaşılması gibi özelliklerinden dolayı anket tekniği kullanılmıştır.

Veri toplama aracı olarak kullanılan anket formu demografik sorular (10 soru), Örgütsel İklim (25 soru) ve Liderlik Stilleri (34 soru) ölçekleri ile toplamda üç bölümden oluşmaktır. Ankette yer alan örgütsel iklim ve liderlik stilleri ifadelerine katılımcıların 5'li likert tipi ölçeğe göre yanitlamaları istenmiştir. Bu doğrultuda zincir otel işletmesinde çalışan personelin her bir ifade ile ilgili katılım derecelerini; “5-Kesinlikle Katıllyorum”, "4-Katıllyorum”, "3-Ne Katıllyorum Ne Katılmıyorum", "2-Katılmıyorum" ve "1-Kesinlikle Katılmıorum" seçenekleri doğrultusunda değerlendirmeleri istenmiştir.

Anket çalışması, turizm sektöründeki çalışma temposunun yoğunluğu göz önüne alınarak 01-30 Ağustos 2015 tarihleri arasında gerçekleştirilmiştir.

\section{Araştırmada Kullanılan Ölçekler}

\section{Örgüt İklimi Ölçeği}

Robert Stringer tarafından geliştirilmiş olan Örgüt İklimi Ölçeği, araştırmacı Hocaniyazov'un 2008 'de yaptığı araştırmadan alınmıştır. Yapılan normallik analizi sonucunda veriler normal dağılım göstermiş ve güvenirlilik analizi sonucunda ölçeğin güvenirlilik katsayısı 0.92 olarak ölçülmüş̧tür.

\section{Liderlik Stilleri Ölçeği}

Liderlik stillerini ölçen anket ise 1990 yılında Bass ve Avolio tarafından geliştirilen Çok Faktörlü Liderlik (Multifactor Leadership) ölçeğidir. Araştırmacı Kılıçarslan'ın 2013 yılında yaptığı araştırmadan alınmıştır. Yapılan normallik analizi sonucunda veriler normal dağılım göstermiş ve güvenirlilik analizi sonucunda ölçeğin güvenirlilik katsayısı 0.90 olarak elde ölçülmüştür.

\section{Verilerin Analizi}

Araştırmada elde edilen verileri analiz etmek amacıyla SPSS 22 (Statistical Package for Social Sciences) paket programı kullanılmıştır.

Örgüt iklimi ile liderlik stilleri arasındaki ilişkiyi belirlemek için Pearson Korelasyon Analizi yapılmıştır. Kolerasyon analizi, bir değişkenin diğer bir değişken ile ilişkisinin ölçülmesine aracılık etmektedir (Kozak, 2014). Korelasyon analizi sonucunda hesaplanan "korelasyon kat sayısı" " $r$ " ile gösterilir. Korelasyon kat sayısı olan $r-1$ ile +1 arasında bir değer alabilir. Kolerasyon kat sayısının işareti (+ ya da - oluşu) ilişkinin doğru veya ters olduğunu gösterir (Yazıcıoğlu ve Erdoğan, 2007). Değişkenler arasındaki ilişkinin düzeyi, korelasyon katsayısının 0 - 0.29 arasında olması durumunda zayıf veya düşük, $0.30-0.64$ arasında olması durumunda orta, 0.65 - 0.84 arasında olması durumunda kuvvetli/yüksek, 0.85 - 1 arasında olması durumunda ise çok kuvvetli/çok yüksek şeklinde yorumlanabilir (Ural ve Kılıç, 2006). 


\section{BULGULAR}

Bu bölümde öncelikle çalışanların demografik ve çalışma özelliklerine ilişkin bilgiler sunulmuş, ardından örgüt iklimi ile liderlik stilleri arasında anlamı bir ilişki olup olmadığına dair korelasyon analizinin sonuçlarına yer verilmiştir.

\section{Demografik ve Çalışma Özelliklerine İlişkin Bulgular}

Tablo 1 Katılımcılara Ait Demografik ve Çalışma Özelliklerine İlişkin Bulgular

\begin{tabular}{|c|c|c|}
\hline Demografik Faktörler & Frekans & $(\%)$ \\
\hline \multicolumn{3}{|l|}{ Cinsiyet } \\
\hline Kadin & 97 & 25.0 \\
\hline Erkek & 291 & 75.0 \\
\hline \multicolumn{3}{|l|}{ Yaş Grubu } \\
\hline $18-27$ & 158 & 40.7 \\
\hline $28-37$ & 158 & 40.7 \\
\hline $38-47$ & 52 & 13.4 \\
\hline 48 ve üstü & 20 & 5.2 \\
\hline \multicolumn{3}{|l|}{ Medeni Durum } \\
\hline Bekâr & 194 & 49.9 \\
\hline Evli & 195 & 50.1 \\
\hline \multicolumn{3}{|l|}{ Eğitim Durumu } \\
\hline İlköğretim & 128 & 32.9 \\
\hline Lise & 206 & 53.0 \\
\hline Ön Lisans & 41 & 10.5 \\
\hline Lisans & 13 & 3.3 \\
\hline Yüksek Lisans & 1 & 0.3 \\
\hline \multicolumn{3}{|l|}{ Alınan Eğitim } \\
\hline Turizmle İlgili & 246 & 64.1 \\
\hline Turizmle İlgili değil & 138 & 35.9 \\
\hline \multicolumn{3}{|l|}{ İşletmedeki Çalışma Şekli } \\
\hline Sezonluk & 231 & 59.4 \\
\hline Sürekli & 151 & 38.8 \\
\hline \multicolumn{3}{|l|}{ Günlük Çalışma Süresi } \\
\hline 6-8 saat & 242 & 62.9 \\
\hline 9-11 saat & 115 & 29.9 \\
\hline 12 saat ve üzeri & 28 & 7.3 \\
\hline \multicolumn{3}{|l|}{ Sektör Tecrübesi } \\
\hline 1 yıldan az & 41 & 10.5 \\
\hline $1-3$ y1l & 109 & 28.0 \\
\hline $4-6$ y1l & 85 & 21.9 \\
\hline $7-9$ y1l & 56 & 14.4 \\
\hline 10 yildan fazla & 98 & 25.2 \\
\hline \multicolumn{3}{|l|}{ İşletmedeki Tecrübe } \\
\hline 1 yıldan az & 135 & 34.8 \\
\hline $1-3$ yil & 122 & 31.4 \\
\hline $4-6$ y1l & 98 & 25.3 \\
\hline $7-9$ y1l & 13 & 3.4 \\
\hline 10 yıldan fazla & 20 & 5.2 \\
\hline \multicolumn{3}{|l|}{ Aylık Gelir } \\
\hline 1000 TL'den az & 27 & 7.1 \\
\hline $1001-1600 \mathrm{TL}$ & 158 & 41.5 \\
\hline $1601-2200 \mathrm{TL}$ & 143 & 37.5 \\
\hline 2201 TL ve üzeri & 53 & 13.9 \\
\hline
\end{tabular}


Tablo 1'e bakıldığında katılımcıların büyük bir kısmının erkeklerden oluştuğu; \% 81,4'ünün 1837 yaş arasında gruplandığı; evli ve bekar oranlarının neredeyse eşit düzeye olduğu; çoğunluğunun lise mezunu ve turizm eğitimi almış olduğu; büyük bir kısmının sezonluk ve günde ortalama 6-8 saat çalıştığı; turizm sektöründeki tecrübelerinin 1-3, 4-6 ve 10 yıldan fazla şeklinde dengeli bir dağılım gösterdiği; çalışılan işletmedeki tecrübenin daha çok 1-6 yıl arasında seyrettiği; ve son olarak aylık gelir düzeylerinin \%79 ile 1001-2200 aralığında yoğunlaştığ görülmektedir. Demografik bulgulara bakıldığında kadın çalışan sayısının az olması dikkat çekicidir. Bunun nedeni sezonluk çalışma oranının yüksek olması ile de açıklanabilir. Ayrıca mutfak çalışanlarının gelir düzeylerinin günümüz şartları açısından son derece düşük olduğu görülmektedir. Aynı işletmede çalışma süresinin daha çok 1-6 yıl olarak en alt skalada toplanması da mutfak departmanında işgücü devir hızının çok yüksek olduğunu göstermektedir.

\section{Ölçeklerin Faktör Analizi Sonuçları}

Araştırmada kullanılan ölçeklerin faktör analizi değerleri Tablo 2 ve Tablo 3'te görülmektedir.

Tablo 2 Örgüt İklimi Ölçeğinin Faktör Analizi

\begin{tabular}{|l|c|}
\hline \multicolumn{2}{|c|}{ Örgüt İklimi Faktör Analizi (Tek Faktör) } \\
\hline KMO & 0.919 \\
\hline Bartlett's Test & 5861.040 sig= 0.000 \\
\hline Toplam varyansı açıklam oranı & 58.331 \\
\hline Güvenirlik katsayısı & 0.92 \\
\hline Faktör Yükü & 0,591 \\
\hline
\end{tabular}

Örgüt İklimi ölçeğinin yapı geçerliliğinin sınanabilmesi için faktör analizi uygulanmıştır. Örneklem büyüklüğünün yeterliliğini test etmek için Kaiser-Meyer-Olkin (KMO) ve analizde elde edilen korelasyon matrisinin birim matris olduğunu göstermek için Barlett Sphericity testi yapılmıştır. Buna bağlı olarak, Barlett Test's of Sphericity değeri anlamlıdır. Örgüt İklimi ölçeğinin KMO değeri 0,919'dur. Analizde varimax döndürme ile 25 iterasyon gerçekleşmiş olup ölçeğin öz değeri birden büyük bir boyut belirlenmiştir ve bu boyut toplam varyansın \%58.331'ünü açılamaktadır.

Tablo 3 Liderlik Stilleri Ölçeğinin Faktör Analizi

\begin{tabular}{|c|c|c|c|c|c|}
\hline Faktörler & 1 & 2 & 3 & 4 & 5 \\
\hline Varyans açıklama oranı & 18.870 & 17.723 & 12.622 & 7.267 & 4.628 \\
\hline Faktör 1: Karizma & 0,647 & & & & \\
\hline Faktör 2: Entelektüel Destekleyici & & 0.680 & & & \\
\hline Faktör 3: Pasizfe Serbest & & & 0,716 & & \\
\hline Faktör 4: Karma & & & & 0,631 & \\
\hline Faktör 5: Değer Aktaran & & & & & 0,837 \\
\hline KMO & \multirow{2}{*}{\multicolumn{5}{|c|}{$\begin{array}{r}0.931 \\
6150.113, \operatorname{sig}=0.000\end{array}$}} \\
\hline Bartlett's Test & & & & & \\
\hline Toplam varyansı açıklam oranı & \multicolumn{5}{|c|}{61.111} \\
\hline Güvenirlik katsayısı & & & & & 0.90 \\
\hline
\end{tabular}


Liderlik Stili ölçeği yapı geçerliliğinin sınanabilmesi için faktör analizi uygulanmıştır. Örneklem büyüklüğünün yeterliliğini test etmek için Kaiser-Meyer-Olkin (KMO) ve analizde elde edilen korelasyon matrisinin birim matris olduğunu göstermek için Barlett Sphericity testi yapılmıştır. Buna bağlı olarak, Barlett Test's of Sphericity değeri anlamlıdır Liderlik Stili ölçeğinin KMO değeri 0,931'dir Analizde varimax döndürme ile 7 iterasyon gerçekleşmiş olup Liderlik Stili öz değeri birden büyük dört boyut belirlenmiş ve dört boyut toplam varyansın \%61,111'ünü açıklamaktadır.

Anketin 35 maddesine yapılan faktör analizi sonucunda liderlik stilleri ölçeği; Karizmatik Entelektüel Destekleyici, Pasifize Serbest ve Karma stil olmak üzere 4 faktörden oluşmuştur. 8 ifadenin faktör yükleri birbirine yakın olduğu için faktör analizi yapılırken çıkarılmış ve değerlendirilmeye alınmamıştır. Böyle yapılmasının nedeni katılımcıların bu 8 ifadeyi aynı anlamda algılıyor olması veya ölçülmek istenen konuyu tam olarak ölçemiyor olmasıdır. Beşinci faktör altında 1 değişken yer almaktadır. Bir faktörü bir değişken tek başına açılayamayacağından analizlerde 4 faktör değerlendirmeye alınmıştır.

\section{Örgütsel İklim ile Liderlik Stilleri Arasındaki İlişki}

Araştırmanın uygulandığı zincir otel işletmesinin mutfak bölümünde çalışanlara liderlik eden üstlerinin liderlik stilleri ile mutfaktaki örgütsel iklim arasındaki ilişkiyi belirlemek amacyyla gerçekleştirilen Pearson Korelasyon Analizi sonucu Tablo 3'te görülmektedir.

Tablo 4 Örgütsel İkim ile Liderlik Stili Arasındaki Pearson Korelasyon Analizi

\begin{tabular}{|c|c|c|c|c|c|}
\hline \multicolumn{2}{|c|}{ Liderlik Stilleri } & Karizmatik & $\begin{array}{l}\text { Entelektüiel } \\
\text { Desteklevici }\end{array}$ & $\begin{array}{l}\text { Pasif } \\
\text { Serbest }\end{array}$ & Karma \\
\hline \multirow{3}{*}{ 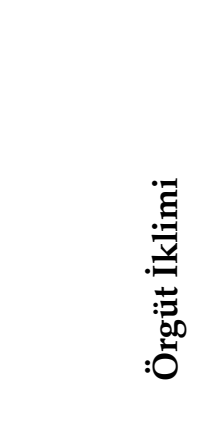 } & $\mathbf{r}$ & 0.612 & 0.616 & 0.361 & 0.443 \\
\hline & $\mathbf{P}$ & 0.000 & 0.000 & 0.000 & 0.000 \\
\hline & $\mathbf{N}$ & 358 & 358 & 356 & 360 \\
\hline
\end{tabular}

Katılımcılar tarafından algılanan örgüt iklimi ile liderlik stilleri arasında istatistiksel açıdan ilişki olup olmadığını belirlemek üzere yapılan Pearson Korelasyon Analizi sonucunda mutfak departmanındaki örgüt iklimi ile karizmatik liderlik stili arasında orta derecede ve pozitif yönlü $(r=0,30<0.612<0,64)$, entelektüel destekleyici liderlik stili ile orta derecede ve pozitif yönlü $(r=$ $0,30<0.616<0,64)$, pasifize serbest liderlik stili ile orta derecede ve pozitif yönlü ( $r=$ $0,30<0.361<0,64)$ ve karma liderlik stili ile orta derecede ve pozitif yönlü $(r=0,30<0.443<0,64)$ anlamlı bir ilişki olduğu saptanmıştır.

Örgüt ikimi ile liderlik stili arasındaki korelasyon analizi tablosu genel olarak değerlendirildiğinde; karizmatik liderlik ile entelektüel destekleyici liderlik stillerinin 
katsayısının pasifize serbest liderlik ve karma liderlik stillerinin katsayısından daha yüksek olduğu görülmektedir. Dolayısıyla bu iki liderlik stili ile örgüt iklimi arasındaki ilişkinin diğer liderlik stillerine göre daha güçlü olduğu söylenebilir.

\section{TARTIŞMA SONUÇ VE ÖNERİLER}

İnsanlar var oluşundan beri dünyada yaşamlarını sürdürebilmek için sosyalleşmeyi öğrenmiş ve topluluk halinde yaşadıklarında dış doğaya karşı daha güçlü olduklarını keşfetmişlerdir. Toplu halde yaşamanın sonucunda oluşan bazı durumlarda, bazı bireyler diğerlerinden daha baskın olmuş ve diğerleri bunu kabul etmişlerdir. Dolayısıyla bu etkileşim sonucu ön planda olan kişilerin grup içinde liderlik rolünü üstlenmiştir. Sosyalleşmenin getirdiği görevleri kendi aralarında paylaşmışlar ve birlikte çalışma ortamlarını yani örgüt iklimlerini oluşturmuşlardır.

Örgüt iklimi ve liderlik, birçok araştırmacının merakını uyandırmış ve çalışmalarında farklı şekillerde tanımlamış ve boyutlandırmışlardır. Yapılan literatür taramasında bu iki kavramın ilişkisinin turizm alanında çalışılmamış olması bu araştırmanın literatüre sağlayacağı katkılar açısından önemlidir.

Araştırmada elde edilen demografik bulgulara bakıldığında mutfak departmanını daha çok erkek çalışanların tercih ettiği görülmektedir. İleri yaşlardaki insanların oranının az olması da mutfak bölümünün uzun vadeli bir kariyer açısından cazip görülmediği düşüncesini doğurmaktadır. 388 çalışandan sadece 13 tanesinin lisans eğitimi almış olması, mutfak departmanının sağladığı kariyer olanaklarının yüksek öğrenim görmüş insan kaynağına hitap etmediği sonucunu ortaya koymaktadır. Ortalama olarak üç çalışandan birisinin turizm eğitimine sahip olmadığ 1 görülmektedir ve yine ortalama üç çalışandan birisi sürekli statüde çalışmaktadır. Turizm sektörünün emek yoğun karakteristiği göz önüne alındığında mutfak departmanındaki işgörenlerin çalışma sürelerinin görece düzenli olduğu söylenebilir. Çalışamların ortalama \%50'si 1-6 yıl arası sektörde çalışıyorken ortalama \%66'sının 1-3 yıldır aynı işletmede çalışıyor olması turizm sektörünün kronik sorunlarından birisi olan işgücü devir hızının hala çok yüksek olduğunu aynı zamanda mevsimselliğin de düşük ücret düzeyleri ile beraber hâlâ sektörün temel dinamiklerinden biri olduğunu göstermektedir.

$\mathrm{Bu}$ araştırmanın temel amacı olan, örgüt iklimi ile liderlik stilleri arasında ilişkinin belirlenmesine yönelik yapılan Pearson Korelasyonuna Analizine göre, örgüt iklimi ile liderlik stilleri arasında pozitif ve orta düzeyli bir ilişki olduğu ortaya çıkmıştır. Araştırma bulgularında incelemeye alınan otel zincirinin Mutfak şeflerinin liderlik stillerinden karizma ve entelektüel destekleyici boyutlarının pasifize serbest yönetim ve karma boyutlara göre daha çok anlamlı çıkması çalışanların daha çok bu liderlik davranışlarını sergileyen bir yönetici ile çalışmayı tercih ettiklerini ortaya koymuştur. entelektüel destekleyici ve karizma boyutların özellikleri olan takım ruhunu aşılama, hedeflerin gerçekleştirilmesi için duyulan güven, probleme farklı açılardan bakmayı sağlama, takipçileri eğitmeye zaman ayırma, çalışanların güçlü yönlerini geliştirmesine yardımcı olma, izleyenlerin yöneticileriyle çalışmalarında etken rol oynaması diğer liderlik boyutlarına göre daha çok tercih edilmesini sağlamaktadır.

Araştırmada elde edilen bulgulardan iki önemli sonuç ortaya çıkmıştır: Birincisi, çalışanların izledikleri liderlik stilleri farklı olsa bile örgütsel iklimin pozitif olması, çalışanlar açısından kendilerine liderlik eden üstlerinin motive edici olumlu davranışlara sahip olduğunu göstermektedir. İkincisi, günümüz mutfak yöneticilerinin geleneksel liderlik uygulamalarından sıyrılarak modern liderlik boyutlarını sergileyen liderler olması sektör açısından oldukça olumlu bir gelişmedir. 
Örgüt iklimi ile liderlik stilleri arasındaki ilişkiyi belirlemeye yönelik olarak yapılan araştırmanın sonucuna dayanarak şu öneriler getirilebilir:

- Turizm Sektöründe çalışan mutfak yöneticilerine, liderlik stillerinin çalışanları nasıl etkilediği hakkında eğitimler verilebilir. Böylelikle hangi davranışların olumlu çıktılar sağladığı konusunda bir farkındalık oluşturulabilir.

- Sezon sonuna doğru işten ayrılma düşüncesi örgüt iklimini olumsuz etkilediği için çalışma şartları tekrar gözden geçirilebilir. Daha doyurucu ücret veya kısmi zamanlı çalışma opsiyonları ile örgüte olan bağllık canlı tutulabilir.

- Çıkan bu sonuçlar doğrultusunda işletme yöneticilerinin örgüt iklimini daha iyi anlayabilmeleri için yöneticilerin yansıttığı liderlik stilleri açısında kendilerini test edip, çalışanların algıladığı liderlik stili ile var olan durum arasındaki benzerlikler ve farklılıklar irdelenebilir.

- Yapılan bu araştırmayı geliştirmek için gelecekteki araştırmacılar işletmelerin diğer bölümlerine de aynı konuda anket formlarını çalışanlara uygulayabilir ve çıkan sonuçlar karşılaştırılabilir.

- Araştırmanın sonuçları ile zincir restoranlarda da yapılacak benzer bir araştırmanın sonuçları karşılaştırmalı olarak analiz edilebilir.

$\mathrm{Bu}$ araştırmadan elde edilen bulgular, örgüt ikliminin kavramsal yapısı gereği (her örgütün iklimi kendine özgü olacağ 1 için) tek bir örgüt kapsamında elde edilmiştir. Gelecekteki araştırmacılar farklı işletmelerde aynı konuyu çalışarak turizm sektöründeki işletmelerin iklim özelliklerindeki baskın eğilimi saptama noktasında katkılar sağlayabilirler.

\section{KAYNAKÇA}

Akat, İ. (1984). İşletme Yönetimi. Üçel Yayımcılık, İzmir.

Akbolat, M., Işık, O., ve Yılmaz, A. (2013). Dönüşümcü Liderlik Davranışının Motivasyon ve Duygusal Bağlllığa Etkisi. International Journal of Economic and Administrative Studies, 6(11), 35-50.

Bakan, İ., Büyükbeşe, T., Erşahan, B., ve Kefe, İ. (2013). Kadın Çalışanların Yöneticilere İlişkin Algıları: Bir Alan Çalışması. Çankırı Karatekin Üniversitesi İktisadi ve İdari Bilimler Fakültesi Dergisi, $3(2), 71-84$.

Bal, Y., ve Ertemsir Berkin, E. (2010). Toplam Kalite Yönetimi Bağlamında Örgüt İkliminin İncelenmesi ve Bir Enerji Şirketinde Uygulama. Yönetim, 21(65), 107-129.

Bass, B. M., and Avolio, B. J. (1990). Transformational Leadership Development: Manual for the Multifactor Leadership Questionnaire. Palo Alto, CA: Consulting Psychologists Press.

Başaran, İ. E. (1998). Yönetimde İnsan İlişkileri-Yönetsel Davranış (2.baskı). Nobel Yayınevi, Ankara.

Bellou, V., ve Andronikidis, A. I. (2009). Examining organizational climate in Greek hotels from a service quality perspective, International Journal of Contemporary Hospitality Management, 21(3), 294-307.

Campbell, J. J., Dunnette, M. D., Lawler, E. E. and Weick, K. E. (1970). Managerial behavior, performance, and effectiveness. New York, NY, US: McGraw-Hill.

Can, H., Akgün, A., ve Kavuncubası, Ş. (2001). Kamu ve Özel Kesimde İnsan Kaynakları Yönetimi (4.Baskl). Siyasal Kitabevi, Ankara. 
Cherrington, D. J. (1989). Organizational behavior: The management of individual and organizational performance, Allyn \& Bacon Inc., Boston.

Çakır, S. Ü. (2010). Örgütsel İklim ile İş Tatmini İlişkisi: Ankara Üniversitesi Tıp Fakültesi Cebeci Araştırma ve Uygulama Hastanesi Örneği. Ankara Üniversitesi Sağllk Bilimleri Enstitüsü, Yayınlanmamış Yüksek Lisans Tezi, Ankara.

Eraslan, L. (2004). Liderlik Olgusunun Tarihsel Evrimi, Temel Kavramlar ve Yeni Liderlik Paradigmasının Analizi. Milli Eğitim Dergisi, Sayı:162, erişim:08/06/2015, http://dhgm.meb.gov.tr/yayimlar/dergiler/Milli_Egitim_Dergisi/162/eraslan.htm

Eren E. (2003). Yönetim ve Organizasyon (Çağdaş ve Küresel Yaklaşımlar). Beta Yayınevi, İstanbul.

Erçetin, S. (1998). Lider Sarmalında Vizyon. Önder Matbaacılık, Ankara.

Ergeneli, A. (1995). Örgütsel Etkililik Kriteri Olarak Lider Davranışının Örgütsel İklim İle İlişkisi: Görev Karmaşıklığı Bakımından Farklılaşan İki Örgüte İlişkin Bir Uygulama. Ankara Üniversitesi Siyasal Bilgiler Fakültesi Dergisi, 50(1),187-199.

Ertekin, Y. (1978). Örgüt İklimi. Türkiye Ve Orta Doğu Amme İdaresi Enstitüsü. Doğan Basım, Ankara.

Forehand, G. A., Gilmer, V. H. (1964). Environmental variation in studies of organizational behavior. Psychological Bulletin, 62(6), 361-382.

Gül, Ö. (2012). Örgütsel İklim Ve İletişim İklimi Arasındaki Etkileşim: Omu Vakfı İşletmeleri Üzerine Bir Araştırma. T.C. Dumlupınar Üniversitesi Sosyal Bilimler Enstitüsü İşletme Anabilim Dalı, Yayınlanmamış Yüksek Lisans Tezi.

Gülertekin, S. (2013). Duygu İklimi ve Liderlik Tarzının İşten Ayrılma Niyetine Etkileri: Alanya'daki Turizm İşletmelerine Yönelik Bir Araştırma. Yayınlanmamış Yüksek Lisans Tezi. T.C. Çanakkale Onsekiz Mart Üniversitesi Sosyal Bilimler Enstitüsü Turizm İşletmeciliği Anabilim Dalı.

Güney, S. (2012). Liderlik. Nobel Yayınevi. Ankara.

Halis, M., ve Uğurlu, Ö. Y. (2008). Güncel Çalışmalar Işığında Örgüt İklimi. İş, Güç, Endüstri İlişkileri ve Insan Kaynakları Dergisi, 10(2), 102-123.

Hellriegel, D., and Slocum, J. W. (1974). Organizational climate: Measures, research and contingencies. Academy of Management Journal, 17(2), 255-280.

Hocaniyazov, A. (2008). Ağırlama İşletmelerinde Örgütsel İklim ve Liderlik. T.C. Dokuz Eylül Üniversitesi Sosyal Bilimler Enstitüsü Turizm İşletmeciliği Anabilim Dalı Turizm İşletmeciliği Programı, Yayınlanmamış Yüksek Lisans Tezi.

Holloway, J. B. (2012). Leadership Behavior and Organizational Climate: An Empirical Study in a Non-profit Organization. Emerging Leadership Journeys, 5(1), 9-35.

İbicioğlu, H., Özmen, H. İ., ve Taş, S. (2009). Liderlik Davranışı ve Toplumsal Norm İlişki: Ampirik Bir Çalışma. Süleyman Demirel Üniversitesi İktisadi ve İdari Bilimler Fakültesi Dergisi, $14(2), 1-23$.

James, L. A., and James, L. R. (1989). Integrating work environment perceptions: explorations into the measurement of meaning. Journal of Applied Psychology, 74, 739-751.

James, L. R., and Jones, A. P. (1974). Organizational climate: A review of theory and research. Psychological Bulletin, 81 (12), 1096-1112. 
Karcioğlu, F. (2001). Örgüt Kültürü ve Örgüt İklimi İlişkisi. Atatürk Üniversitesi İktisadi İdari Bilimler Fakültesi Dergisi, 15(1-2), 265-283.

Kets de Vries, M. (2007). Liderliğin Gizemi. (Çev. Dicleli Z. eserin Orjinali 2006 yılında yayımlandı). MESS Yayın No:25, İstanbul.

Kılıç, R., Keklik, B., ve Yıldız, H. (2014). Dönüştürücü, Etkileşimci ve Tam Serbesti Tanıyan Liderlik Tarzlarının Örgütsel Sessizlik Üzerindeki Etkisini Belirlemeye Yönelik Bir Araştırma. Celal Bayar Üniversitesi İ.I.B.F. Yönetim Ve Ekonomi Dergisi, 21(2), 249-268.

Koçel, T. (2007). İşletme Yöneticiliğii, İstanbul: Arıkan Basım Yayım.

Korkmaz, M. (2007). Örgütsel Sağlık Üzerinde Liderlik Stillerinin Etkisi. Kuram ve Uygulamada Ĕ̆itim Yönetimi, 49, 57-91.

Kozak, M. (2014). Bilimsel Araştırma: Tasarım, Yazım ve Yayım Teknikleri. Detay Yayıncılık, Ankara.

Kuei, C. H., Madu, C. N., Lin, C., and Lu, M. H. (1997). An empirical investigation of the association between quality management practices and organizational climate. International Journal of Quality Science, 2(2), 121-137.

Kundu, K. (2007). Development of The Conceptual Framework of Organizational Climate. Vidyasagar University Journal of Commerce, 12, 98-108.

Lewin, K., Lippitt, R. and White, R. K. (1939). Patterns of aggressive behavior in experimentally created "social climates. Journal of Social Psychology, 10, 271-299.

Newbold, P. (2000). Işsletme ve İktisat için İstatistik (4. Basımdan çev. Ümit Şenesen). Litaratür Yayıncılık, İstanbul.

Özdoğan, B. (2014). İşe yabancılaşma, örgütsel iklim ve koçluğun iş tatminine etkileri üzerine istanbul ilinde ampirik bir çalışma (Yayınlanmamış Yüksek Lisans Tezi). Beykent Üniversitesi SBE, İstanbul.

Özel, M. (1998). Liderlik Sanatı. İz Yayıncilık, İstanbul.

Özkalp, E. (1988). Örgütsel Davranış. Eskişehir: Anadolu Üniversitesi Açık öğretim Fakültesi Yayınları, No: 40.

Pala, E. (2011). Öğretmenlerin Örgüt İlkimi Algılamalarına Yönelik Bir Çalışma: Edirne Kız Teknik ve Meslek Lisesi Örneği (Yayınlanmamış Yüksek Lisans Tezi). Trakya Üniversitesi SBE, Edirne.

Patterson, M.G., West, M. A., Shackleton, V.J., Dawson, J.F., Lawthom R., Maitlis, S., Robinson, D.L. and Wallace, A. (2005). Validating The Organizational Climate Measure: Links To Managerial Practices, Productivity and Innovation. Journal of Organizational Behavior, (26), 379408.

Rızaoğlu, B. ve Hançer, M. (2005). Menü ve Yönetim. Ankara, Detay Yayıncilık.

Sabuncuoğlu, Z. ve Tüz, M. (2003). Örgütsel Psikoloji. Furkan Ofset, Bursa.

Saylı, H. ve Baytok, A. (2014). Örgütlerde Liderlik Teori Uygulama ve Yeni Perspektifler. Ankara, Nobel Yayınevi.

Sims, H. P. and La Follette, W. (1975). An Assessment of the Litwin and Stringer Organization Climate Questionnaire. Personnel Psychology, (28),19-38.

Şişman, M. (2014). Öğretim Liderliğì (5. Baskı). Pegem Akademi Yayıncılık. Ankara. 
Taşkıran, E. (2005). Otel İşletmelerinde Liderlik Ve Yöneticilerin Liderlik Yönelimleri: İstanbul'daki Beş Yildızlı Otel İşletmelerinde Bir Araştırma. T.C Abant İzzet Baysal Üniversitesi Sosyal Bilimler Enstitüsü Turizm ve Otel İşletmeciliği Anabilim Dalı, Yayınlanmamış Yüksek Lisans Tezi.

Tinaz, P. (2013). Çalışma Yaşamından Örnek Olaylar. Beta Yayınları, İstanbul.

Tutar, H. ve Altınöz, M. (2010). Örgütsel İklimin İşgören Performansı Üzerine Etkisi: Ostim İmalat İşletmeleri Çalışanları Üzerine Bir Araştırma, Ankara Üniversitesi SBF Dergisi, 65(2), 219237.

Ural, A. ve Kılıç, İ. (2006). Bilimsel Araştırma Süreci ve SPSS Veri Analizi. Detay Yayıncılık, Ankara.

Waters, L. K., Roach, D. and Batlis, N. (1974). Organizational climate dimensions and job-related attitudes. Personnel Psychology, 27(3), 465-476.

Wofford, J.C., Goodwin, V.L. and Whittington, J.L. (1998). A Field Study of a Cognitive Approach to Understanding Transformational Leadership. The Leadership Quarterly, 9(1), 55-83.

Yavuz, E. (2009). İş görenlerin Dönüşümcü Liderlik ve Örgütsel Bağlllık İle İlgili Tutumlarına Yönelik Bir Araştırma. İşletme Araştırmaları Dergisi, 1(2), 51-69.

Yavuz, E. ve Tokmak, C. (2009). İş görenlerin Etkileşimci Liderlik Ve Örgütsel Bağlllık ile İlgili Tutumlarına Yönelik Bir Araştırma. International Journal of Economic and Administrative Studies, $1(2), 17-35$.

Yazıcıoğlu, Y., Erdoğan, S. (2007). SPSS uygulamalı Bilimsel Araştırma Yöntemleri. Detay Yayıncılık, Ankara.

Yılmaz, H. (2008). Stratejik Liderlik (1.Baskl). Kum Saati Yayınları. İstanbul.

Zel, U. (2001). Kişilik ve Liderlik. Seçkin Yayıncılık, Ankara. 